УДК 340.132

DOI https:// doi.org/10.32837 / yuv.v0i6.2062

Ю. Безкоровайна,
аспірантка Інституту права

Київського національного університету імені Тараса Шевченка

\title{
ПРАВОВЕ РЕГУЛЮВАННЯ ЯК ОБ'ЄКТ СОЦІОЛОГІЧНОГО ТИПУ ПРАВОПІЗНАННЯ
}

Вступ. Важливим напрямом будьякого наукового дослідження є методологічний, зокрема той, що стосується вивчення теоретико-правових аспектів правового регулювання відносин у сфері функціонування об'єднань співвласників багатоквартирного будинку, що $є$ загальним предметом наукового пошуку автора статті. Методологічна складова частина будь-якого сучасного наукового дослідження явищ i процесів правової дійсності, зокрема теоретико-правових аспектів правового регулювання відносин в тій чи іншій сфері людської діяльності, відіграє важливу роль, забезпечуючи всебічність, повноту та перспективність самого наукового дослідження. Формування пізнавальної основи дослідження та методологічного інструментарію дослідження $є$ першочерговим завданням будь-якого вченого-юриста, забезпечуючи формування у нього методологічної стратегії наукового дослідження загалом.

Насамперед варто звернути увагу на те, що проблематика правового регулювання в пізнавальному аспекті не є новою та відзначається тривалою історією свого світоглядного осмислення та наукового дослідження. Зокрема, окремі пізнавальні аспекти правового регулювання розкривались як ученими - теоретиками права (С.В. Бобровник, Т.О. Дідич, O.M. Мельник, Н.М. Оніщенко, T.I. Тарахонич), так і вченими - представниками галузевих юридичних наук (А.Б. Авер'янов, В.Д. Бабкін, В.Ф. Погорілко). Водночас слід від- значити, що проблематика правового регулювання сьогодні не отримала необхідного світоглядного та доктринального розроблення, а наявність в юридичній науці цілої низки різних і подекуди не пов'язаних між собою поглядів, окремих ідей та суб'єктивних міркувань щодо деяких аспектів правового регулювання не свідчить про високий рівень концептуального осмислення феноменологічних, гносеологічних та онтологічних аспектів правового регулювання. На нашу думку, недостатній рівень наукового й світоглядного осмислення правового регулювання обумовлений неоднозначністю підходів до праворозуміння та правопізнання, що не дає змогу надати однозначну відповідь на питання регулятивного впливу права. В методологічному аспекті важливо посилити саме пізнавальну основу вивчення теоретико-правових аспектів правового регулювання, що має засновуватись на положеннях відповідних типів праворозуміння, центральне місце серед яких посідає соціологічний тип праворозуміння.

мета статті. 3 урахуванням вказаного вище, відзначаючи високий рівень наукової та практичної витребування дослідження правового регулювання крізь призму положень соціологічного типу праворозуміння, вважаємо за доцільне в наукові роботі на підставі аналізу поглядів представників соціологічної юриспруденції з'ясувати особливості розуміння правового регулювання, а також виокремити перспективні напрями наукового 
дослідження правового регулювання, засновуючись на положеннях соціологічного типу праворозуміння.

Основна частина. Світоглядні уявлення про правове регулювання мають глибоке історичне коріння та зароджуються у поглядах мислителів періоду Античності (з ХІ ст. до н. е. по $\mathrm{V}$ ст. н. е.), протягом якого було сформовано перші погляди на право як елемент всесвіту, що виникає і розвивається об'єктивно, є складовою частиною природи, поділяється на природне й позитивне, кожне з яких характеризується функціональним призначенням, можливістю співвідношення крізь призму його дієвості та досягнення мети. В цей період зароджуються перші теологічні уявлення про право, призначенням якого $€$ поширення на людей релігійних канонів, недопущення порушень таких засад співжиття людей, як загальна любов до ближнього, повага, терпіння та взаємна підтримка. Фактично хоча саме поняття «правове регулювання» не було виокремлено, проте слід відзначити зародження його світоглядного сприйняття як такого, що впливає на людей, визначає критерії (вимоги) їх поведінки та націлене на досягнення конкретної правової мети. Період Середньовіччя (V ст. - середина XV ст. н. е.) розвиває уявлення про право та критерії його виміру як такого, що має неухильно відповідати релігійним канонам, а його поширення на суспільство забезпечується усвідомленням людьми того, що право $є$ божественним благом, яке турбується про людей та веде ï до спасіння через взаємну любов та терпіння один до одного. Фактично в період Середньовіччя було закладено основні засади сприйняття права як явища, що має закономірності свого зародження та виникнення, а також відзначається своєю націленістю на досягнення певного впорядковуючого впливу життя суспільства. Період Нового часу (кінець XV ст. кінець XVII ст.) доповнює уявлення про право як про явище, що забезпечує кожній людині їі автономність та ідентифікацію в природному, соціальному та правовому середовищі. Наслідком цього стало виокремлення перших ідей про права людини та іï свободи, визначення їх змісту, обгрунтування принципів рівноправності та справедливості у взаємовідносинах між людьми, протидії сваволі людини, межею якої $є$ права та свободи інших індивідів. Право все більше розглядається як особливий інструмент закріплення та в подальшому забезпечення автономності й ідентифікації людини. У період Нового часу хоча саме поняття «правове регулювання» ще не виокремлюється, проте було закладено основу для його виокремлення та подальшого тлумачення як процесу та засобу виміру досягнення правового ефекту, забезпечення автономності людини, іï ідентифікації, визначення чітких меж між свободою та свавіллям людини, між правами й свободами одної людини та правами й свободами іншої тощо. Окрім того, правові вчення Нового часу загалом заклали основу для відмежування церковного права від світського (державного), що виявляється в аспекті його поширеності на суспільні відносини, сфер прояву та націленості на досягнення правового результату насамперед у різноманітних сферах життєдіяльності суспільства, не пов'язаних зі сферою релігії, діяльності духовенства та церкви тощо. Змістом зазначеного правового результату як одного з аспектів відокремлення світського права від церковного $€$ націленість на викорінення несправедливості, формування системи правових засобів забезпечення справедливості, досягнення максимальної відповідності позитивного права нормам і принципам права природного, побудова світського суспільства, в якому панують світське право та світська правова система загалом. Окремо можна виокремити особливості розвитку правових уявлень у період Просвітництва 
(кінець XVII ст. - кінець XVIII ст.), яке характеризується загалом світоглядним і методологічним переосмисленням права, зокрема крізь призму його телеологічного сприйняття, яке за сутністю, змістом та роллю $€$ зумовленим єдиною метою, а саме справедливістю, законністю, рівністю та братерством як самоціллю права. Незважаючи на те, що правове регулювання ще не виокремлюється як самостійна категорія в системі понять та категорій філософії і права, можна відзначити те, що в цей період обгрунтовуються ідеї про прямопропорційну залежність між метою творення права та змістом творення права, що пов'язано насамперед із націленістю на забезпечення прав людини, їх реалізацією та гарантуванням. Сам процес творення права орієнтований на досягнення правового результату, що відбувається крізь призму розумової діяльності людини, розумового сприйняття кожною людиною змісту своїх правових можливостей, меж своєї свободи у сфері права. Уявлення про право доповнились низкою ідей, які в подальшому становитимуть окремі аспекти (підходи) до характеристики правового регулювання в сучасному його розумінні. Насамперед ідеться про визнання широкого кола факторів суспільного розвитку як основи, що детермінує утворення права та в подальшому являє собою об'єкт правового впливу задля досягнення певного стану впорядкованості суспільних відносин за допомогою права, і така впорядкованість загалом визначатиме творення права, його подальший розвиток, удосконалення тощо. Зазначений процес впливу факторів творення права та подальшого зворотного впливу права на суспільні відносини має взаємний, циклічний та безперервний характер, отже, визначається змінюваність права як невід'ємна його особливість. Відповідно, правове регулювання є таким, що має змінюваний характер та визначається, 3 одного боку, змінами в житті суспільства, які виявляються у факторах творення права, а з іншого боку, змінами в самому праві, що впливає на суспільні відносини відповідно до динаміки зміни самого права. $\mathrm{У}$ цей період відроджуються та переосмислюються уявлення про природне право, яке визначається через його мету. Мета права полягає в тому, що воно (право) має бути поширене на суспільні відносини, які, зрештою, повинні відповідати засадам природного права. Таким чином, умовно можна визначати засади природного права як загальну мету права позитивного, що виступатимуть умовою його регулюючого впливу, критерієм його дієвості та ефективності. Договірний характер походження права, його соціально орієнтоване сприйняття та поширення на суспільні відносини, що отримує своє переосмислення в поглядах філософів Нового часу, так само розглядаються крізь призму узгодження суспільних інтересів, і саме ця узгодженість може визначатись як прототип сучасного розуміння дієвості права, що являє собою iii досягнення за допомогою відповідних форм і методів правового регулювання. В цей період досить активно виокремлюються властивості права, зокрема моральність права, тобто його відповідність устоям конкретного суспільства, його культурі, уявленням про добро і зло, справедливість і несправедливість, належне та допустиме; розумність права, що засновується на інтелектуальних здібностях людини виявляти об'єктивну необхідність права, його формалізувати та в подальшому правильно сприймати зміст його положень, проводити його тлумачення та застосування, виявляти його недоліки та визначати шляхи їх усунення; доступність та зрозумілість права як його юридично-технічні характеристики, що дають змогу закріпити й передати інформаційний зміст права; людиновимірність права як універсальний засіб закріплення автономності людини не лише 
як природної і соціальної істоти, але й як суб'єкта права, суб'єкта правової сфери життя суспільства. Розкривається вченими зміст цих властивостей права, які стають чинниками для того, щоб ідентифікувати право, відмежувати його від права несправедливого, асоціального, такого, що порушує природні основи життя людини, суспільного устрою. Трансформуючи ці уявлення на площину розуміння правового регулювання, маємо відзначити, що регулювання являє собою невід’ємну властивість права, що виявляється в його:

- спроможності акумулювати в собі історично сформовані основи життя конкретного суспільства, його соціокультурні цінності, які закріплюються за допомогою права, а також допомогою права посилюється їх регулюючий потенціал;

- заснованості на інтелектуальних здібностях людини щодо вияву об'єктивної необхідності права, його формалізації, спроможності в подальшому бути правильно сприйнятим, розтлумаченим та застосованим, тим самим реалізованим, що за своєю сутністю є поєднанням змісту й результату правового регулювання;

- доступності та зрозумілості, що дають змогу передати регулюючий зміст права від суб'єкта, що його формалізує, до суб'єкта права;

- людиновимірності, що виступає універсальним засобом закріплення автономності людини не лише як природної і соціальної істоти, але й як суб'єкта права, суб'єкта правової сфери життя суспільства, спроможного корелювати свою поведінку відповідно до змісту права.

Початок XIX ст. зумовлений суттєвим розвитком широкого кола підходів до праворозуміння, що зумовлено визнанням права як особливого об'єкта світоглядного та наукового сприйняття. Протягом XIX ст. інтенсивно розвиваються погляди вчених, які умовно отримують свою структуризацію на типи праворозуміння.
Правове регулювання також грунтовно переосмислюється представниками природної, позитивістської, історичної, психологічної та інших шкіл праворозуміння. Водночас, на нашу думку, найбільш грунтовний внесок у характеристику правового регулювання зробили представники соціологічного типу праворозуміння, зародження та активний розвиток якого припадають на XIX ст. Так, Є. Ерліх у своїх працях зазначає, що право саме по собі походить від недоліків правової сфери життя суспільства, а їх усунення буде свідченням ефективності права [1, с. 55], причому такий процес виникнення недоліків та їх усунення за допомогою права свідчить про так зване живе право, яке трансформується залежно від зміни таких недоліків та результату ї усунення [2], тобто відображає процес дії права, фактично його регулятивний вплив. Характеризуючи погляди Є. Ерліха, В.В. Костицький зауважує, що аналіз положень теорії $€$. Ерліха дає змогу констатувати, що вчений визнавав суспільство єдиним можливим джерелом права, водночас не відкидав ролі держави, яка «творчо втручається в суспільне життя. Хоч воно і не створює своє право методом копіювання відносин, що склалися в суспільстві, а творить нові відносини для задоволення суспільних потреб, державна влада запозичить тільки те, що відповідає їі інтересам» [3, с. 58; 4, с. 98-99]. Такий зв'язок суспільства як джерела права та держави як творця права, джерелом якого є суспільство, характеризує фактично особливості правового регулювання, що походить від суспільства, твориться державою та в подальшому впливає на те саме суспільство. На переконання В.В. Костицького, «визначивши основою суспільного розвитку право, Є. Ерліх започаткував нове бачення змісту права як феноменального явища, створюваного самим суспільством, назвавши таке право «живим правом». Саме це право лежить 
в основі правозастосування, прирікаючи «на смерть» норми державного права, якщо вони суперечать нормам моралі, справедливому суспільному правопорядку» [3, с. 59-60]. Такий соціологічний підхід до розуміння права, що виявляється в його походженні від суспільства та подальшого зворотного регулятивного впливу на суспільство, характеризує право як живе (що закладено в основу концепції $Є$. Ерліха про «живе право». Ю. Б.), відповідно, правове регулювання можна розглядати крізь призму такого циклічного механізму існування права.

Доцільно згадати також погляди М.М. Ковалевського, М.М. Коркунова та С.А. Муромцева, які розглядають правове регулювання крізь призму його здатності забезпечити розмежування різноманітних інтересів та встановити тим самим соціальний порядок [5, с. 10; 6, 272-273]. Аналіз поглядів представників соціологічної школи права цілком обгрунтовано доводить, що ці науковці виступали за спрямування правового регулювання, зрештою, на особисті інтереси людини [7, с. 4-5], надаючи праву сенсуалістичного розуміння, вкладаючи в нього ідею націленості на результат. В межах аналізу соціологічного розуміння права варто згадати погляди Б.О. Кістяківського та П.О. Сорокіна, які доповнюють уявлення ідеями про право як про багатоаспектний феномен, регулятивна ефективність якого вимірюється за допомогою різноманітних критеріїв, сформульованих для виміру кожного окремо взятого аспекту. Зокрема, Б.О. Кістяківський окремо виділяє серед них соціальний та психічний виміри [8, с. 196-200], які фактично покликані охарактеризувати дієвість права та визначити рівень його ефективності. П.О. Сорокін підходить до характеристики правового регулювання $з$ точки зору його інструментального розуміння, наголошуючи на необхідності виокремлення критеріїв такого регулювання, до яких пропонує віднести розумність державної влади та доцільність іï політики, культурність та цивілізованість суспільства, умови та галузь правового регулювання [9, с. 342]. 3 точки зору феноменології характеризує регулятивну ефективність права М.М. Алексєєв, який наполягає на тому, що регулятивне функціональне призначення права $є$ насамперед складовою частиною характеристики самого права. Рівень правового регулювання визначається насамперед рівнем його входження у загальний ракурс зміни правових норм як самостійних явищ духовного життя [5, с. 10].

Слід відзначити, що сьогодні серед численних поглядів учених на проблематику правового регулювання проблематика однозначності його розуміння залишилась детально недослідженою та нерозробленою. Здебільшого автори обмежуються згадками про окремі підходи до визначення правового регулювання, наголошують на окремих поглядах тих чи інших філософів, науковців, які опосередковано стосуються питань розуміння правового регулювання. Сьогодні вкрай важливо посилити дослідження правового регулювання, особливо крізь призму панівних підходів до розуміння права, центральне місце серед яких, на нашу думку, посідає соціологічний підхід, що дає змогу поєднати характеристику правового регулювання як взаємодію процесу поширення права на суспільні відносини та результату правового впливу

Висновки. За результатами проведеного дослідження вважаємо за доцільне окремо звернути увагу на перспективи наукового дослідження теоретико-правових аспектів правового регулювання крізь призму положень соціологічного типу правопізнання. До таких перспектив можна віднести такі:

1) подальше наукове дослідження правового регулювання потребує насамперед подолання пануючого в юридичній

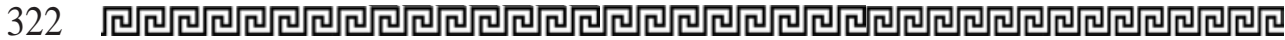


науці вузького інструментального підходу до розуміння регулятивного впливу права та переходу до широкого його тлумачення як складного та багатоаспектного явища, що $€$ самостійним напрямом функціонування права, змістом якого є соціалізація права, націлена на досягнення покладеної на нього мети; відповідно, слід посилити вивчення теоретико-правових та практичних аспектів правового регулювання крізь призму його широкого розуміння не лише як засобу реалізації правотворчого волевиявлення, але й як багатоаспектного явища, що $є$ невід'ємною властивістю права, його сутністю та складовою частиною його функціонального призначення;

2) здійснення наукового дослідження правового регулювання потребує подолання заідеологізованості представлених в юридичній науці поглядів на явище права та його ролі, що сформувалися в радянській юридичній науці та в подальшому впливають на сучасні наукові дослідження правового регулювання, що обумовлено сприйняттям права суто як засобу (інструменту) в руках правлячого соціального класу, що спроможне закріпити, поширити та забезпечити реалізацію його інтересів за допомогою загальнообов'язкової сили права;

3) наукове дослідження правового регулювання потребує посилення методологічного забезпечення, особливо щодо визначення методологічної стратегії його пізнання; на нашу думку, основу такої методологічної стратегії мають становити положення соціологічного типу правопізнання, що в основу дослідження вкладають ідеї суспільних відносин як першоджерела права; об'єкта правового регулювання; результату правового регулювання у вигляді трансформаційних перетворень кількісних і якісних показників суспільного життя.

y статті автором обтрунтовано високий рівень наукової та практичного витребування дослі- дження правового регулювання. Підсумовано, що методологічна складова частина будь-якого сучасного наукового дослідження явищ $i$ процесів правової дійсності, зокрема теоретико-правових аспектів правового регулювання відносин в тій чи іншій сфері людської діяльності, відіграє важливу роль, забезпечуючи всебічність, повноту та перспективність самого наукового дослідження.

Автором на підставі аналізу поглядів представників соціологічної юриспруденції з'ясовано особливості розуміння правового регулювання, а також виокремлено перспективні напрями наукового дослідження правового регулювання з огляду на положення соиіологічного типу праворозуміння. У висновку узагальнено зазначені перспективні напрями наукового дослідження, до яких віднесено подолання пануючого в юридичній науці вузького інструментального підходу до розуміння регулятивного впливу права та переходу до широкого його тлумачення як складного та багатоаспектного явища, що є самостійним напрямом функціонування права, змістом якого є соціалізачія права, націлена на досягнення покладеної на нього мети; подолання заідеологізованості представлених у юридичній науці поглядів на явище права та його ролі, що сформувалися в радянській юридичній науці та в подальшому впливають на сучасні наукові дослідження правового регулювання, шо обумовлено сприйняттям права суто як засобу (інструменту) в руках правлячого соціального класу, що спроможне закріпити, поширити та забезпечити реалізаиію його інтересів за допомогою загальнообов'язкової сили права; посилення методологічного забезпечення дослідження, особливо щодо визначення методологічної cmpamегіï його пізнання. На нашу 
думку, основу такої методологічної стратегіi мають становити положення соціологічного muпy правопізнання, що в основу дослідження вкладають ідеї суспільних відносин як першоджерела права; об'єкта правового регулювання; результату правового регулювання у вигляді трансформаціиних перетворень кількісних $i$ якісних показників суспільного життя.

Ключові слова: право, правовий вплив, правове регулювання, соціологічний тип праворозуміння, правовий плюралізм.

Bezkorovayna Yu. Legal regulation as an object of sociological type of legal knowledge

The author substantiates the high level of scientific and practical demand for the study of legal regulation. It is concluded that the methodological component of any modern scientific study of phenomena and processes of legal reality, including theoretical and legal aspects of legal regulation of relations in a particular field of human activity, plays an important role in ensuring the comprehensiveness, completeness and viability of scientific research.

Based on the analysis of the vieres of representatives of sociological jurisprudence, the author clarifies the peculiarities of understanding legal regulation, as well as identifies promising areas of research on legal regulation, based on the provisions of the sociological type of legal understanding. In conclusion, these promising areas of research are summarized, which include: 1) overcoming the prevailing in legal science narrow instrumental approach to understanding the regulatory impact of law and the transition to its broad interpretation as a complex and multifaceted phenomenon, which is an independent direction of law. there is a socialization of law aimed at achieving its goal; 2) overcoming the ideology of the views presented in legal science on the phenomenon of law and its role, formed in Soviet jurisprudence and further affect modern scientific research of legal regulation, due to the perception of law purely as a means (tool) in the hands of the ruling social class able to consolidate, disseminate and ensure the realization of its interests through the binding force of law; 3) strengthening the methodological support of the study, especially in terms of determining the methodological strategy of its knowledge. In our opinion, the basis of such a methodological strategy should be the provisions of the sociological type of legal knowledge, which are based on the study of the ideas of social relations as: a) the primary sources of law; $b$ ) the object of legal regulation; $c$ ) the result of legal regulation in the form of transformational transformations of quantitative and qualitative indicators of public life.

Key words: law, legal influence, legal regulation, sociological type of legal understanding, legal pluralism.

\section{Література}

1. Марчук В.П. «Свободное право» в буржуазной юриспруденции: Критика концепций Е. Эрлиха. Киев, 1977. 167 с.

2. Эрлих Е. Основоположение социологии права / пер. с нем. М.В. Антонова; под ред. В.Г. Графского, Ю.И. Гревцова. Санкт-Петербург : Университетский издательский консоризиум, 2011. 704 с. URL: http: / / nashol.com/2015071285699/ os novopolojenie-sociologii-pravaerlih-o-2011.html (дата звернення: 31.10.2020).

3. Костицький В.В. Про значення теоретичної спадщини Є. Ерліха у розвитку сучасного праворозуміння. Науковий часопис НПУ ім. М.П. Драгоманова. 2016.Bun.31.C.57-63.URL:http: / / enpuir.npu. edu.ua / bitstream / 123456789 / 18975 / 1 / Kostytsky.pdf (дата звернення: 12.09.2020).

4. Костицьький В.В., Кобан О.Г. Соцзіологія права: науково-теоретична спадщина 


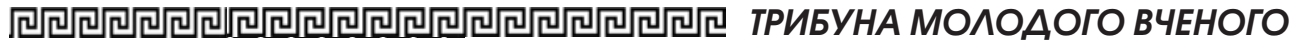

Євгена Ерліха і проблеми розвитку сучасної науки. 2-ге вид. Київ : Коло, 2016. 255 с.

5. Нугаева Н.Р. Проблема әффективности права в истории отечественного правоведения. История государства и права. 2015. № 21. С. 8-13.

6. Коркунов Н.М. Лекции по общей теории права. 2-е изд., стер. Москва : Юрайт, 2018. 422 c.

7. Ємельяненко К.С. Позитивістський ma соиіологічний підходи до розуміння ефективності правового регулювання. Часопис Академії адвокатури України. 2013. № 19. С. 1-6.

8. Кистяковский Б.А. Философия и соииология права / сост., примеч., указ. B.В. Сапова. Санкт-Петербург : РХГИ, 1999. 800 C.

9. Сорокин П.А. Эффективность деятельности государства. Теория государства и права : хрестоматия. Москва: Юрuсmъ, 1998. C. 340-358. 